\title{
A Survey on the Demand and Willingness to Pay for the Service of the Residents in Changchun City
}

\author{
Dongmei Sun \\ Department of Home Economics, College of Humanities, Jilin Agricultural University, Changchun \\ 130118, China. \\ Sundongmei-1975@qq.com
}

\begin{abstract}
With the rapid economic development, people's pursuit of life quality is getting higher and higher, at the same time, domestic service has gradually come into people's lives. This paper studies the relationship between the demand for home service and the willingness to pay for the community residents in Changchun. From the content of domestic service, service quality, form, price, standardization of domestic companies, residents' disposable income and household structure type, the survey is adopted. This paper studies the social factors of imbalance between supply and demand of domestic service, and puts forward the strategies and suggestions for the standardization of domestic market and the establishment of new domestic service corporation.
\end{abstract}

Keywords: Domestic service; demand will; willingness to pay; influencing factors.

\section{Object and Method of Investigation}

\subsection{Survey Object and Introduction.}

The investigation object is the resident family area of Jilin Agricultural University in Jilin province Changchun Jingyue Economic Development Zone. The community belongs to the Yongxing streets covering an area of nearly 6 square kilometers, a total of 4964 residents, 12375 people. The old man in the old agricultural proportion accounted for more than $80 \%$ and there are 21 staff members of the community.

\subsection{Method of Investigation.}

This paper adopts the methods of questionnaire survey and field interview. Questionnaire survey is conducted to investigate the demand, willingness and the influencing factors of domestic service. A total of 250 questionnaires are issued, and 240 questionnaires are returned. Field interviews are conducted in the process of questionnaire survey with appropriate exchanges, similar to the field interview. It can get the inconvenience information in the questionnaire to reflect the issues to consult.

\section{Results of Questionnaire Analysis}

\subsection{Analysis of Residents' Demand for Home Service.}

The content is mainly about dealing with the housework and tends to diversify. Through the survey, we find that, for the community residents, a majority of the family needs to hire a housekeeper, mainly to deal with the housework. Table 1 shows the contents of demand for home service.

Table 1 Residents' willingness of demand for domestic service content

\begin{tabular}{|c|c|c|}
\hline Home service content & Number of people & Proportion \\
\hline Home cleaning & 120 & $50 \%$ \\
\hline Geriatric nursing & 35 & $14.6 \%$ \\
\hline Home education & 8 & $3.3 \%$ \\
\hline Child caring & 47 & $19.6 \%$ \\
\hline Family financial management & 20 & $8.3 \%$ \\
\hline Others & 10 & $4.2 \%$ \\
\hline Total & 240 & $100 \%$ \\
\hline
\end{tabular}


The survey finds that home cleaning and other daily chores content occupy 50\%, elderly care accounts for $14.6 \%$, pregnant nursery occupies $19.6 \%$, other types is less than $10 \%$. It shows that the demand for home service is the main part, and other types of services also occupy a certain proportion. The overall service demand tends to be diversified.

Table 2 The ways of residents choose for home service

\begin{tabular}{|c|c|c|}
\hline Choice of home service & Number of people & Proportion \\
\hline Regular company & 144 & $60 \%$ \\
\hline Intermediary introduction & 25 & $10.4 \%$ \\
\hline Acquaintances introduction & 58 & $24.2 \%$ \\
\hline Community introduction & 13 & $5.4 \%$ \\
\hline Total & 240 & $100 \%$ \\
\hline
\end{tabular}

The selection method tends to be regularized (Table 2). Through the survey we find that $60 \%$ of the residents hire housekeeping staff through the regular company, 24.2\% through acquaintances friends, $10.4 \%$ through the introduction of the intermediary and 5.4\% through the community. This shows that the hiring of domestic service channels diversifies, and a large part of family choose the formal home service corporation.

Focus on domestic service specialization and standardization. Through the survey we find that when choosing home service, $24.6 \%$ people will choose the company with good reputation, $27.9 \%$ will choose according to a reasonable price and $27.4 \%$ will choose the company with a strong professional. And $83 \%$ of the home service will be chosen by the formal domestic service. Service prices are becoming more and more reasonable, of which $60.8 \%$ are satisfied with the price of home services.

\subsection{Factors of Residents' Demand.}

Disposable income of residents. Residents' disposable income is the income that is obtained in the survey period and can be used freely by the residents. The home service demand of community residents is influenced and restricted by various factors, among which the disposable income of residents is the most important factor to realize the control of domestic demand. The income status of the working people directly restricts the change of the acceptable degree of the home service. Through the survey we find that employers can accept the price of domestic workers most tend to 1500--2500 yuan, the senior staff may be a little higher.

Family structure type. Through the investigation and analysis, it can be concluded that different families need the same domestic service. And the different factors that affect the family structure are different. If a family is the core family then it needs the service is the housework or family education, but if there is an elderly people in the family, it may need to care for the elderly.

Occupation and education level of residents. Through the analysis of the questionnaire survey, the influence of occupational and educational level of residents is also important. Survey results show that civil servants, business executives, teachers, marketing personnel and individual business operators take the proportion of $19.4 \%, 16.8 \%, 21.5 \%, 10.5 \%$ and $16.5 \%$, respectively in using housekeeping service. In these occupations, $90 \%$ of the people are educated for bachelor degree or above. So the occupation and education level of residents have different influence on the cognition and consumption of domestic service.

\subsection{Analysis of Residents' Willingness to Pay for Home Service and its Influencing Factors.}

The cost of home service the residents are willing to pay. Residents' pay willingness, also known as price will, refers to the amount of money that consumers are willing to pay for a certain amount of consumer goods or services. This is the consumer's personal evaluation of a particular item or service, with a strong subjective assessment of the composition. $80 \%$ residents participating in the survey are willing to pay 1500-2500 yuan in the cost of home service. The income of wage earners directly 
restricts the range of acceptable levels of their remuneration to home service, and for most ordinary residents, the amount of money paid for home service is 1500-2500.

The quality of home service, the quality of the service personnel and the disposable income of the residents are the main factors that affect the willingness of the residents to pay (Table 3).

Table 3 Reasons of Customers choosing home economics company

\begin{tabular}{|c|c|c|c|c|}
\hline Reason & Service quality & Service personnel quality & Price & Enterprise brand \\
\hline Proportion & $48.6 \%$ & $25.4 \%$ & $14.3 \%$ & $11.7 \%$ \\
\hline
\end{tabular}

When customers choose home service, quality of service and service personnel is still the main factor in customer choice of domestic Service Corporation, followed by price factors and corporate reputation. Now we can know that the focus of the market for domestic service is still the quality and service skills of domestic workers. Survey results show that the satisfaction of home service price is quite good. In the real consumer group, a considerable number of people have good understanding of home service, which also contributes to the willingness to pay for this service.

\section{Conclusion}

(1) Building Domestic Service Information Network Platform.

At present, with the increasing range of home service in Changchun, the service division of labor becomes more refined and the service level of employees still cannot meet the needs of the current market. Professional home service personnel are still in need. This will inevitably require the domestic service industry to develop with market demand-oriented. This needs to establish a market feedback mechanism, strengthen market supervision, achieve full and reasonable allocation of resources and train more professional service personnel. We can use policy guidance and enterprise market operation mode to improve the level of domestic service industry information. We should pay more attention on creating a number of platform which can share industry information, dock supply and demand and protect consumption. A public information platform established in the network center for the public can provide supply and demand docking services. Relying on the platform of the network center, we can integrate all kinds of family services resources, form a convenient home service network. In the platform, we can conduct supervision and evaluation of enterprise quality, service quality, standardize the service standards, and guide enterprises to provide quality, reasonable price of home services.

(2) Transform Government Functions and Regulate the Development of the Industry.

The government and its business departments must, in accordance with the requirements of the transformation of functions, to assist all levels of industry organizations, strengthen management measures, standardize management and formulate relevant policies and regulations, such as a legal registration procedures, a clear division of responsibilities, the establishment of the domestic service industry standardization system, the legitimate business contract or agreement, etc., Establish a domestic service enterprises for record registration, supervision and acceptance of complaints system and websites and advisory services.

In the process of promoting the development of domestic service, the labor and social security department should provide the full range of services for the laid-off workers, unemployed workers and other workers in the process of promoting the development of domestic service. Through the development of national professional standards, the preparation of vocational training materials, the implementation of assessment and certification, a unified training institutions and training standards system can be built in order to improve the quality of employees. Strengthen the norms of management, provide labor contracts and labor contract samples, and guide the signing of labor contracts. With the develop methods of social insurance and dispute resolution, the reliability of the service can be improved. Strengthen the protection of the rights and interests of the maintenance, to enhance the stability of domestic service industry. In this process, we should implement employment 
access and certificate system gradually. Also we should sound labor contract system, encourage more workers to join the domestic service industry and improve the overall quality of the team.

(3) Strengthen the Publicity Work and Popularize the Education of Home Service.

The government should play a leading role to meet the needs of the community and guide the consumption of residents. The socialization of home service refers to the development process from the closed to open, the service object from the special to universal, the service content from single to complex, and the service mode from single channel to multi-channel. The goal of socialization is the social benefit and economic benefit. The result of the socialization of home service is that more members of society can enjoy the service and it can help people to understand the home service. It is conducive to the development of domestic service corporation. Combined with the reality, we can use all kinds of propaganda tools and forms to widely publicize the national economy status, function and significance of the domestic service industry.

(4) Enterprises Should Strengthen the Training and Improve the Quality of Employees.

The company should strengthen the professional training of domestic service workers, so that it can change the concept of employment, master the necessary knowledge and skills of family services, so as to establish a correct professional ethics and employment awareness. This can improve the quality of domestic service workers, and thus improve the quality of service.

\section{References}

[1] Tong Yi, Gong Jian, Wang Jianzhou. The development characteristics of domestic and foreign domestic service industry and Its Enlightenment to Beijing [J]. Contemporary economy. 2011 (21):23-25.

[2] Jiang Yun Chang. The international experience of the development of home service industry [J]. Economic research reference, 2010 (56).

[3] Chen Chen. Research on the professional quality of domestic workers and their cultivation [J]. Vocational education, 2011 (03):92-93.

[4] Zhou Zhao. Dilemma and countermeasures in the course of the professionalization of Home service [J]. Journal of Yangling Vocational and Technical College, 2010 (03):45-47 